\begin{tabular}{|l|c|c|c|c|}
\hline Submission & Review Process & Revised & Accepted & Published \\
\hline $07-02-2021$ & $10-02$ s/d 17-04-2021 & $21-04-2021$ & $26-04-2021$ & $28-04-2021$ \\
\hline
\end{tabular}

Published by: Politik Islam UIN Raden Fatah Palembang

\title{
Politik Identitas: Peran Politik Etnis Tionghoa dalam Pemilihan Walikota dan Wakil Walikota Palembang Tahun 2018
}

\author{
Muhammad Yoga Anugrah \\ Fakultas Adab dan Humaniora Universitas Islam Negeri Raden Fatah Palembang \\ Email: myogak97@gmail.com \\ M. Syawaluddin \\ Fakultas Adab dan Humaniora Universitas Islam Negeri Raden Fatah Palembang \\ Email: mohammadsyawaludin_uin@radenfatah.ac.id
}

\begin{abstract}
This study discusses the role of the ethnic Chinese in the city of Palembang in the 2018 election of mayor and deputy mayor who are members of the PITI organization (Indonesian Chinese Islamic Association). The PITI organization is not like other organizations that express direct and open support in supporting one of the colon pairs. It can be said that the PITI organization located in the city of Palembang appears to be less open to political activities or classified as closed. Because in terms of number PITI does not have as many members as other community organizations.

The formulation of the problem in this study, namely: First, how is the political participation of ethnic Chinese in the election of mayor and deputy mayor of Palembang in 2018. Second, the factors that influence the participation of ethnic Chinese in the election of mayor and deputy mayor of Palembang in 2018.

The methods in this study include descriptive qualitative methods and use data collection techniques through direct interviews with informants as primary sources. In addition, as a secondary source of information obtained through books, journals, and previous scientific writings. The interviews were conducted with the deputy general chairman, treasurer, and members of PITI in Palembang.

The results of this study indicate that the political participation of the PITI organization in the 2018 election of the mayor and deputy mayor of Palembang is neutral towards their political choices. However, neutral means that the PITI organization does not invite its members to choose one candidate from the four pairs of candidates, but members are free to make their choices and influence their friends as long as they are not in the official activities of the PITI organization. Furthermore, the factors that affect PITI's political participation are the lack of openness to the colony pair or the candidate's success team, so that PITI can be said to be shy and even tends to be closed in the election activities.
\end{abstract}


Keywords: PITI, political participation, local election

\begin{abstract}
ABSTRAK
Penelitian ini membahas peranana etnis Tionghoa yang berada di kota Palembang dalam pemilihan walikota dan wakil wlikota tahun 2018 yang tergabung dalam organisasi PITI (Persatuan Islam Tionghoa Indonesia). Orgsnisasi PITI tidak seperti organisasi lainya yang menyatakan dukungan secara langsung dan terbuka dalam mendukung salah satu pasangan colon. Dapat dikatakan bahwa organisai PITI yang berada di kota Palembang namapaknya kurang teralu membuka terhadap kegiatan politik atau tergolong tertutup. Karena dari segi jumlah PITI tidak memiliki banyak anggota seperti organisasi masyarakat lainya.

Adapun rumusan masalah pada penelitian ini, yaitu: Pertama, Bagaimana partisipasi politik etnis Tionghoa dalam pemilihan walikota dan wakil walikota Palembang tahun 2018. Kedua, Faktor-faktor yang mempengaruhi partisipasi etnis Tionghoa dalam pemilihan walikota dan wakil walikota Palembang tahun 2018.

Metode dalam penelitian ini termasuk metode kualitatif deskriftif dan menggunakan teknik pengumpulan data melalui wawancara langsung dengan narasumber sebagai sumber primer. Selain itu, sebagai sumber sekunder informasi diperoleh melalui buku, jural, dan tulisan-tulisan ilmiah terdahulu. Adapun wawancara dilakukan dengan wakil ketua umum, bendahara, dan anggota PITI kota Palembang.

Hasil penelitian ini menunjukan bahwa partisipasi politik organisasi PITI dalam pemilihan walikota dan wakil walikota Palembang tahun 2018 bersikap netral terhadap pilihan politiknya. Namun, netral yang dimaksud ialah secara organisasi PITI tidak mengajak anggotanya memilih salah satu kandidat calon dari keempat pasangan calon, akan tetapi anggota bebas untuk menentukan pilihannya dan mempengaruhi temantemannya asalkan tidak dalam kegiatan resmi organisasi PITI. Selanjutnya adapun fakor yang mempengaruhi partisipasi politik PITI ialah kurang terbukanya terhadap pasangan colon ataupun tim sukses calon, sehingga PITI dapat dikatakan masih bersika malu-malu bahkan cendrung tertutup dalam kegiatan pemilihan tersebut.
\end{abstract}

Keywords: PITI, Partisipasi Politik, Pilkada

\title{
PENDAHULUAN
}

Demokrasi merupakan bentuk pemerintahan dimana kebijakan secara langsung atau tidak langsung ditentukan oleh suara terbanyak dari warga masyarakat yang memiliki hak untuk memilih dan dipilih, melalui wadah pembentukan suaranya dalam keadaan bebas dan tanpa paksaan. Sikap demokratis masyarakat suatu bangsa diwujudkan salah satunya dalam bentuk partisipasi politik. Intensitas partisipasi politik warga masyarakat dalam suatu Pemilihan Umum sering dijadikan tingkat ukuran bagaimana tingkat partisipasi politik masyarakat di suatu negara, utamanya di negara-negara berkembang, seperti Indonesia.

Dalam partisipasi politik masyarakat yang melakukan pemilihan, dapat dipengaruhi oleh faktor sosiologis jika dilihat dari sudut pandang prilaku memilih, yakni kelas sosial, ekonomi, agama, etnis, gender, dan juga aspek daerah tempat tinggal. 
(Mikail, 2018) Ada beberapa faktor utama yang membentuk pengaruh partisipasi di Indonesia salah satunya adalah faktor etnisitas. Palembang merupakan salah satu kota yang terletak di Sumatera Selatan yang ada di Indonesia, yang memiliki banyak sekali keberagaman etnis dan budaya. Salah satu budaya yang ada di kota Palembang adalah Melayu, Tionghoa, dan Arab. Masyarakat yang mendiami kota Palembang diantaranya adalah masyarakat pribumi asli yang merupakan penduduk asli Palembang, namun tidak di pungkiri begitu banyak masyarakat keturunan Tionghoa dan hampir rata-rata menempati kota Palembang.

Di Palembang sendiri, keberadaan masyarakat Tionghoa muslim sebenarnya sudah ada sejak lama. Bahkan terdapat yayasan yang merupakan wadah atau sarana khusus bagi WNI (etnis Tionghoa) yang ingin mempelajari tentang agama Islam. Yayasan tersebut berandil besar dalam melahirkan para muslim dari kalangan etnis. Hingga saat ini pun masih banyak warga Tionghoa khususnya Cina peranakan yang datang ke yayasan tersebut untuk mencari tahu informasi tentang islam. agama merupakan jalan terbaik dalam menghilangkan kesenjangan antara kaum pribumi dengan masyarakat keturunan Tionghoa di Indonesia. Oleh karena itu, yayasan ini selalu berjuang dalam memberikan informasi mengenai Islam khususnya kepada WNI keturunan Tionghoa. Yayasan ini menjadi sarana dalam membina masyarakat etnis Tionghoa maupun pribumi untuk lebih mengenal agama islam dan secara otomatis merupakan ajang berkumpulnya para muallaf etnis Tionghoa dan masyarakat muslim pribumi. Bahkan di palembang sendiri ada masjid yang di dirikan oleh orang-orang tiong hoa yang bernama Masjid Al Islam Muhammad Cheng Hoo Sriwijaya Palembang.

Di Indonesia terdapat juga PITI (Persatuan Islam Tionghoa Indonesia) yakni sebuah organisasi yang menaungi masyarakat Cina muslim se-Indonesia yang telah memiliki berbagai kantor cabang antara lain di daerah Jelambar (Jakarta Barat) dan Tangerang (Jawa Barat). Karena PITI merupakan organisasi masyarakat Tionghoa muslim Indonesia, maka seluruh anggota dan pengurus adalah orang-orang keturunan Tionghoa yang muslim. Berbeda dengan Yayasan. Selain itu, masyarakat yang datang untuk belajar tentang Islam di yayasan ini pun juga orang-orang dari beragam etnis, walaupun sebagian besar adalah masyarakat keturunan Tionghoa.

Terdapat penilaian bahwa keberadaan masyarakat Tionghoa muslim masih merupakan hal yang istimewa atau tidak biasa di mata sebagian besar warga pribumi. Mungkin sebagian besar masyarakat kita tak membayangkan jika ada orang Tionghoa yang memasuki mesjid dan melakukan sholat di dalamnya. Dalam pemikiran sebagian besar masyarakat kita menganggap bahwa orang-orang Tionghoa adalah penganut Kong $\mathrm{Hu} \mathrm{Cu}$, Budha, atau Nasrani. Ketika ia ingin melakukan sholat di masjid dekat tempat tinggalnya, orang-orang yang berada di sekitar masjid hampir seluruhnya memperhatikannya. Mereka semua tidak terbiasa melihat orang yang secara fisik terlihat sebagai orang keturunan Tionghoa memasuki areal masjid apalagi melakukan ibadah sholat di dalamnya. Inilah yang dapat menjadi salah satu bukti bahwa masyarakat Tionghoa dinilai tidak identik dengan agama Islam.

Seperti halnya dikota Palembang banyak masyarakatnya yang keturunan Tionghoa sehingga ada perbedaan pertisipasi politik antara keturunan Tionghoa dengan masyarakat biasa. Mayoritas dari masyarakat Tionghoa di kota Palembang berada di sektor ekonomi dan masih sedikit yang merambah dunia politik. Dengan keberagaman suku yang ada rentan menjadi konflik dan menunjukkan rivalitas antar etnis untuk mengedepankan kepentingan kelompoknya, baik ekonomi, sosial, budaya dan politik. Dengan adanya perbedaan partisipasi politik dikota Palembang maka hal ini dapat diteliti 


\section{Muhammad Yoga Anugrah, Muhammad Syawaluddin Politik Identitas: Peran Politik Etnis Tionghoa dalam Pemilihan Walikota dan Wakil Walikota Palembang Tahun 2018, Ampera: A Research Journal on Politics and Islamic Civilization, Vol. 2 No. 2 April 2021}

dan dapat dicari faktor-faktor yang mempengaruhinya, sehingga data-data yang diambil lebih akurat dan efektif.

Beragamnya identitas etnis yang ada di Palembang, terjadi persaingan antar etnis dalam momentum pilkada, dimana para calon menggunakan simbol identitas etnisnya untuk ditampilkan bahwa ia ingin menunjukkan kepada masyarakat yang memiliki kesamaan etnis dengannya untuk membangun eksistensi dan partisipasi dari kelompok etnis tersebut. Sebagai elit politik yang ingin mendapatkan tempat kekuasaan pada suatu derah yang dapat memanfaatkan dari adanya kelompok-kelompok etnis yang ada. Maka untuk menarik perhatian dan mendapatkan dukungan dari masyarakat, para kandidat melakukan pendekatan-pendekatan dengan perkumpulan dari kelompok etnisnya sendiri maupun dengan kelompok etnis lain, dengan begitu masyarakat yang berasal dari etnis lain merasa adanya kedekatan dan kepercayaan terhadap pasangan calon, dengan tujuan untuk mendapatkan dukungan dari suku lain.

Dengan pendekatan politik simbolis tersebut para kandidat akan mendapatkan respons yang baik dari masyarakat, untuk mendapatkan respons simbolis dapat menggunakan identitas etnis, agama, dan kelompok-kelompok partisipan yang diikuti, dengan harapan simbol-simbol tersebut bisa mempengaruhi kelompok-kelompok yang ada. Para kandidat mengembangkan pemasaran politik untuk memasarkan dirinya maupun idenya biasanya dengan menggunakan ideologi ras atau etnisitas yang dirangkum dalam pesan politik sebagai sebuah strategi pemasaran dalam sebuah kegiatan pemilihan.

\section{TINJAUAN LITERATUR}

Sebuah hasil penelitian umumnya harus adannya rujukan penelitian terdahulu agar terhindar dari kegiatan plagiatisme tanpa mencantumkan sumber peneliti terdahulu yang perna melakukan penelitian serupa. Dalam tinjaun literature ini menunjukan beberapa sumber literatur yang digunakan sebagai sumber rujukan penelitian. Rujukan penelitian digunakan agar ada sisi pembeda dari penelitian sebelumnya, serta ada hal baru apa yang menjadi temuan penelitian sehingga layak menjadi sebuah karya ilmiah. Adapun rujukan yang digunakan ialah sebagai berikut: Pertama, penelitian yang dilakukan oleh Melinda Adi Pratiwi dalam skripsinya yang berjudul Politik identitas dalam perspektif politisi Surabaya. Studi kasus di Dewan perwakilan Rakyat Daerah (DPRD) Kota Surabaya. Penelitian yang dilakukan Melinda ini membahas pandangan politisi yang berasal dari etnis Tionghoa di Surabaya mengenai politik identitas, serta posisi politisi etnis Tionghoa dalam pengambilan kebijakan. Selain itu juga menjelaskan wujud dari keterwakilan etnis Tionghoa di DPRD kota Surabaya.

Kedua, penelitian yang dilakukan oleh Suryani dan Ana Sabhana Azmy pada tahun 2016 dengan judul Politik Identitas dan Nasionalisme Kebangsaan. Studi atas penguatan politik identitas etnis Tionghoa di Indonesia pasca orde baru. Penelitian ini membahas lebih kearah sejarah etnis Tionghoa secara keseluruhan mengenai perkembangannya dari masa ke masa. Khususnya pada masa orde lama hingga pada masa orde baru. Selain itu,fokus penelitian disetiap masa adalah bentuk-bentuk tebentuknya penguatan identitas etnis tionghoa dari berbagai bidang, misalnya ekonomi dan bisnis yang dilakukan oleh etnis Tionghoa.

Ketiga, penelitian yang berjudul Muslim Tionghoa sebagai Jembatan Budaya, Studi tetang Partisipasi dan Dinamika Organisasi PITI Yogyakarta oleh Hamada Adzani Mahaswara. Penelitian Hamada ini membahasa tentang usaha-usaha yang dilakukan PITI kota Yogyakarta baik secara kolektif maupun personal dalam bidang pemberdayaan sosial, dakwah, dan strategi kubudayaan pada masa pasca reformasi. 
Keempat, penelitian Moh. Muhyidin dengan judul Peranan PITI terhadap Islamisasi di Indonesia yang dilakukan pada tahun 2018. Tulisan pada penelitian ini membahas adakah pengaruh organisasi PITI terhadap islamisasi di Indonesia, serta bagaimana bentuk pengaruh tersebut terhadap Islamisasi yang terjadi. Selain itu, membahas juga factor-faktor yang mempengaruhi Islamisasi, seperti perdagangan, perkawinan, dan politik.

Kelima, Perkembangan Agama Islam di Kalangan etnis Tioghoa Semarang tahu 1972-1998 oleh Septian Adi Chandra, dkk. Dalam penelitian ini membahas sejarah perkembangan masuknya agama Islam di kalangan etnis Tionghoa yang beraada di kota Semarang dari tahun 1972-1998. Artinya penelitian Septian fokus meihat Islamisasi etnis Tionghoanya bukan kegiatan politiknya.

Dari beberapa penelitian sebelumnya menunjukan bahwa fokus dan kajian yang dilakukan peneliti memiliki perbedaan yang cukup jelas baik secar isi dan lokasi penelitian, dimana fokus penelitian penulis lebih kerarah partisipasi politik dan factor yang mempengaruhi partisipasi politik tersebut.

\section{METODE PENELITIAN}

Penelitian ini menggunakan metode penelitian deskriptif dengan menggunakan pendekatan kualitatif dengan fokus data yang utama adalah wawancara dan observasi (sumber data primer) dan dokumentasi (sumber data sekunder). Penelitian deskriptif dalam penelitian ini digunakan untuk memaparkan bagaimana partisipasi politik Etnis Tionghoa dalam dalam Pemilihan pemilihan Walikota dan wakil walikota Palembang 2018.

Dilihat dari sumber data yang diperoleh, penelitian ini menggunakan teknik pengumpulan data secara lagsung di lapangan melalui obeservasi dan selanjutnya melakukan wawancara langsung. Selain itu, data diperoleh melalui kajian-kajian literature berupa tulisan karya ilmiah yang bekaitan dengan judul penelitian. Sehingga peneliatan ini tergolong penelitian field research atau penelitan lapangan dikarenakan sumber informasi penelitian banyak diperoleh dengan cara terjun langsung ke lapangan.

\section{HASIL DAN PEMBAHASAN}

Pola partispasi politik PITI dapat dilihat melalui teori partisipasi politik yang diformulasikan oleh Samuel P.Huntington, Adapun bentuk-bentuk partisipasi politik tersebut adalah kegiatan pemilihan, lobby, kegiatan organisasi, contacting dan tindakan kekerasan. Pertama, kegiatan pemilihan. Berdasarkan temuan dilapangan PITI sebagai salah satu organisasi yang memiliki sumber daya manusia tentu menjadi objek politik oleh kandidat atau tim sukses dalam kontestasi pemilihan walikota lalu. Hal ini dilakukan untuk mendulang suara sebanyak-banyaknya pada saat hari pemilihan. Berdasarakan keterangan dari sekretaris PITI kota Palembang membenarkan bahwa ada tim sukses ataupun kandidat mencoba untuk mendekati PITI dengan cara melakukan kegiatan di yayasan masjid Al Islam Chengho.

“ Iya, sebenarnya PITI bersikap netral dalam pemilihan walikota Palembang tahun 2018 lalu tidak memihak kepada kandidat manapun, walaupun ada yang mencoba melakukan pendekatan untuk melakukan tawar-menawar, serta datang untuk mengadakan kegiatan di yayasan masjid Al Islam Chengho. Kalau tidak salah ada dua calon ketika itu. Tapi, kami tanyakan terlebih dahulu maksud dan tujuannya kalau untuk berkampanya kami tidak mengizinkan. Jadi upaya kandidat atau tim sukses 


\section{Muhammad Yoga Anugrah, Muhammad Syawaluddin Politik Identitas: Peran Politik Etnis Tionghoa dalam Pemilihan Walikota dan Wakil Walikota Palembang Tahun 2018, Ampera: A Research Journal on Politics and Islamic Civilization, Vol. 2 No. 2 April 2021}

tersebut tidak bisa kalau mendekati PITI secara organisatoris. Namun, Kalau secara informal kami tidak menutup kemungkinan dilakukan secara individu, karena kami tidak bisa mengatakan bahwa semua anggota kami ada yang ikut terlibat secara langsung atau tidak. itu kembali lagi diserahkan kepada individunya masing-masing. Akan tetapi, secara umum ada."

Kemudian, lebih lanjut hal senada juga dikemukakan oleh wakil ketua umum PITI kota Palembang.

"kalau untuk ikut menjadi tim sukses, panitia pemungutan suara, atau ikut andil lebih jauh dalam kegiatan pemilihan yang lalu, jika mengatasnamakan organisasi kami tidak mengizinkan. Akan tetapi jika atas nama individu ya sah-sah saja. Karena urusan pribadi kita tidak ikut campur, itukan hak anggota untuk menggunakan haknya sebagai warga negara yang baik dalam kontestasi politik. Namun, kalau untuk berpartispasi dalam memberikan suara pada saat pemilhan kami rasa semuanya mengguanakan haknya walaupun kami tidak menjamin 100 persen semuanya mengunakan hak pilihnya."

Dari penjelasan tersebut menunjukkan bahwa tidak terjadinya kontrak politik ataupun PITI mendeklarasikan diri untuk mendukung salah satu pasangan calon atas nama organisasi. Meskipun ada pertemuan antara anggota PITI dengan tim sukses itu hanya sebatas silahturahmi sebagai sesama muslim tidak ada kaitanya dengan minta dukungan pasangan calon. Sedangkan terkait pilihan politik anggota PITI memiliki pilihan yang berbeda-beda, dan tidak bisa dilihat satu persatu. Setiap orang memiliki kecendrungan pilihan politik yang berbeda pula, tergantug orang tersebut melihat dari sudat pandang yang mana dalam melihat pasangan calon. Sesuai dengan teori yang cukup pemiliar dalam budaya politik yang terbagi menjadi budaya politik parokial, budaya politik kaula/subjek, dan budaya politik partisipan.

Kedua, ialah bentuk lobby. Bentuk ini merupakan upaya-upaya yang dilakukan oleh perorangan atau kelompok untuk menghubungi pimpinan politik dengan maksud mempengaruhi keputusan mereka tentang suatu isu. Jika dikaitkan dengan penelitian ini, maka konteks yang akan kita kaji adalah tentang upaya yang dilakukan oleh PITI sebagai organisasi untuk menghubungi kandidat calon atau tim sukses dari calon walikota Palembang dengan maksud untuk mempengaruhi keputusan mereka tentang suatu isu atau tawar-menawar mengenai kesepakatan-kesepakatan politik.Mengenai bentuk partisipasi politik kedua ini, sebenarnya jia dilihat dari sudut pandang pemilu terlihat yang mimiliki kepentingan adalah pasangan calon walikota. Alasanya cukup jelas, karena mereka memerlukan dukungan suara sebanyak-banyaknya untuk memperoleh kemenangan. Terkait dengan proses lobby itu tetap ada sebatas tim sukses mendekati anngota PITI di luar kegiatan organisasi untu mendapatkan dukungan dan nantinya anggota tersebut mengajak kerabat terdekatnya untuk memilih salah satu calon walikota pilihannya. Pernyataan ini diperoleh dari pernyataan salah satu pegurus PITI kota Palembang yang mengatakan:

"seperti tadi saya perna katakan PITI ini netral terhadap pasangan calon manapun, tidak memihak satu dan lainya. Kalau ada yang datang berkunjung ke PITI dengan tujuan dan maksud yang baik kami persilahkan, tapi kalau lebih jauh untuk membahas kepentingan politik kami menolak selaku organisasi. Meskipun nantinya 


\section{Muhammad Yoga Anugrah, Muhammad Syawaluddin Politik Identitas: Peran Politik Etnis Tionghoa dalam Pemilihan Walikota dan Wakil Walikota Palembang Tahun 2018, Ampera: A Research Journal on Politics and Islamic Civilization, Vol. 2 No. 2 April 2021}

ada salah satu anggota yang berpartisipasi atas ajakan salah satu tim sukses calon kami tidak melarang asal tidak mengatasnamakan PITI."

Ketiga, Kegiatan Organisasi.Kegiatan organisai sebagai mana dijelaskan sebelumya bahwa partisipasi individu ke dalam organisasi, baik selaku anggota maupun pemimpinnya, guna mempengaruhi pengambilan keputusan oleh pemerintah. Dalam konteks penulis melihat bahwa organisasi PITI dapat dikatakan cendrung tidak aktif sebagaimana organisasi masyarakat lain pada umumnya yang berperan aktif dalam konsturuksi pemilihan walikota Palembang. Hal ini terlihat bahwa PITI hanya menjalin hubungan hanya sebatas menjalin silahturahmi dan tidak mau masuk lebih jauh kedalam kegiatan politik, apalagi sampai masuk kedalam pendukung partai politik atau pasangan colon. Disamping itu juga, PITI tidak terlalu familiar di masyarakat dan memiliki anggota dengan kuantitas yang cukup sedikit. Senada dengan pernyataan dengan sekretaris PITI kota Palembang.

"Kita ini sebagai organisai keagamaan yang hanya berfokus memepelajari dan mendalami agama dan setelah itu mengajarkan kepada siapa yang mau belajar. Kami tidak mau membahas kepentingan politik kedalam kegiatan-kegiatan organisasi, misalnya pada saat rapat atau acara pertemuan-pertemuan lainya seperti peringatan hari-hari besar Islam.”

Pernyataan yang sama juga dikemukaan oleh wakil ketua umum PITI kota Palembang mengenai keterlibatan PITI dalam pemilihan walikota tahn 2018 yang lalu.

“Apa yang telah dikatakan oleh Ibu Meri itu benar, kita sebagai organisasi keagamaan tidak perna membahas tentang pilihan politik kami secara individu ke dalam kegiatankegiatan organisasi. Kami juga tidak memaksakan anggota kami untuk memilih pasangan calon nomor satu, dua, ataupun seterusnya. Mereka bebas mengekspresikan pilihan politik mereka tanpa ada tekanan dari kami selaku pimpinan organisasi."

Keempat, Contacting. Contacting yaitu upaya individu atau kelompok dalam membangun jaringan dengan pejabat-pejabat pemerintah guna mempengaruhi keputusan mereka. Sebenarnya contacting sudah disinggung pada pembahasan lobby sebelumnya. Dimana pada umumnya pada moment pemilihan kepala daerah sering dimanfaatkan organisasi-organisasi baik bersifat kegaman ataupun masa untuk mendekati pihak yang memiliki kepentingan. Agar terjadi hubungan simobiosis mutualisme, dimana kedua pihak saling diuntungkan baik sebelum ataupun setelah kegiatan pemilihan selesai. Pada kasus ini PITI tidak terlihat pada organisai lain pada umumnya. Kontak yang terjadi dengan salah satu calon tidak berlangsungg secara terus menerus, disebakan PITI tidak memiliki keinginan untuk masuk lebih jauh dalam kegiatan politik. Misalnya, setelah penggurus PITI didatangi salah satu calon untuk melakukan tawar menawar tentang dukungannya nanti di hari pemilihan, PITI tidak menentukan sikap apakah mendukung calon satu atau calon dua. Sehingga, tidak terjadi kontrak-kontrak politik yang dapat menguntungkan kedua bela pihak. Bagi anggota yang ingin bergabung dan tertarik dengan tawaran salah satu calon tidak ada larangan dari pengurus, dengan catatan tidak membahas dalam kegiatan organisasi. Hal ini sejalan dengan apa yang dikatakan oleh salah satu anggota PITI kota Palembang.

"organisasi tidak melarang dan tidak menganjurkan untuk memilih salah satu calon dalam pilkada lalu, kami sebagai anggota diberikan kebebasan dalam menentukan pilihan politik. Saya secara pribadi tahu ada beberapa calon yang mendekati organisasi 
kami, tapi sepertinya organisasi kami memilih untuk bersikap netral. Walaupun saya tidak tahu pasti, pihak yang dihubungi salah sagu calon tersebut melakukan hubungan lebih jauh atau tidak. Meskipun misalnya iya, pilihan mereka tidak diumumkan atau tidak dipublikasikan dalam berbagai kegiatan organisasi."

Selanjutnya ialah Faktor-faktor yang mempengaruhi partisipai politik PITI kota Palembang pada pemilihan walikota dan wakil walikota tahun 2018. Berbicara mengenai faktor-faktor yang dapat mempengaruhi partisipasi politik, tentunya sangat beragam bentuk dan jenisnya. Jika merujuk pada jumlah anggota PITI sendiri untuk wilayah Palembang kurang lebih hanya berjumlah 100 orang, jumlah ini terdiri dari berbagai latar belakang profesi pekerjaan. Dari berbagai latar belakang pekerjaan itulah selanjutnya membentuk pola pikir yang berbeda -beda pula, hal ini dipengaruhi oleh lingkungan dimana mereka bekerja. Sebagaimana telah dijelaskan pada pembahasan kerangka teori yang menyatakan bahwa faktor utama yang mempengaruhi partisipasi politik adalah modernisasi.

Modernisasi dapat mempengaruhi partisipasi politik dikarenakan modernisasi di berbagai bidang, seperti pendidikan, teknologi, media media dan lainya. Pertama, tingkat pendidikan. Tingkat pendidikan merupakan hal yang sangat penting dalam memebentuk pola pikir seseorang dalam melihat perkembangan politik di tempatnya tinggal. Seseorang yang memiliki tingkat pendidikan yang baik tentu memiliki banyak pertimbangan dalam menentukan pilihan politiknya. Sebagaimana pernyataan seketaris PITI kota Palembang sebelumnya yang menjelaskan bahwa baik pengurus dan anggota memiliki latar belakang pendidikan yang berbeda-beda, oleh sebab itulah pilihan politik diserahkan kepada individu masing-masing. Tingkat pendidikan anggota dan pengurus PITI kota Palembang sendiri dari tingkat sekolah menengah hingga magister.

Kedua, media masa. Media masa memiliki peran yang tak kalah penting dalam mempengaruhi pilihan politik seseorang, baik itu media masa elktronik maupun online. Semakin sering seseorang calon walikota mengiklankan dirinya dalam media masa maka semakin ia dikenal oleh masyarakat luas. Media massa memiliki akses yang cepat ke semua lapisan masyarakat, dengan begitu masyarakat dapat mengetahui track record, visi misi calon melalui media masa. Media masa mampu menjual isu-isu yang dapat membawa trend positif bagi salah satu calon, dengan cara menjual isu-isu positif mengenai calon. Menurut salah satu anggota PITI, ia menjelaskan bahwa:

"Saya pribadi memilih calon walikota pada pemilihan lalu berdasarkan rekam jejak
calon, dan visi dan misinya. saya memilih pasangan Harnojoyo dan Fitrianti karena
tertarik dengan visi misinya yaitu, palembang emas darussalam. Disamping itu,
program safari subuhnya yang menurut saya jarang sekali dilakukan walikota lain. Saya
juga mencari informasi di media online mengenai hal-hal yang perna dilakukan ketika
beliau menjabat, jadi media online ini sangat mebantu untuk mendapatkan informasi.
Saya juga membandingkan kelebihan dan kekurangan masing-masing calon agar tidak
salah pilih"

Ketiga, Kelompok Kepentingan. Kelompok kepentingan dalam konteks ini adalah setiap orang yang memiliki kepentingan politik dengan salah satu calon kandidat walikota atau sebaliknya, sehingga berusaha mengumpulkan dukungan sebanyak-banyaknya. Seperti, 
partai politik, tim suskes, serta sukarelawan. Pada Faktor ini sebenarnya banyal disingung pada proses lobby dan contacting, tapi disini lebih menekankan bahwa proses tersebut mempengaruhi pilihan politik. Sudah menjadi kebenaran umum dalam proses politik, bahwa proses mempengaruhi seseorang untuk mengikuti pilihan politiknya adalah sebuah keniscayaan. Misalnya, sebuah tim sukses dari salah satu calon pemenangan mendatangi sekelompok orang atau organisasi masyarakat untuk ikut mendukung calon yang mereka dukung. Nantinya pada hari pencoblosan meskipun persentase tidak mencapai 100 persen, akan tetapi sedikit banyak akan membuahkan hasil dari usaha mempengaruhi tersebut. Pendidikan, media masa, dan kelompok kepentingan merupakan faktor pendukung yang mempengaruhi partisipasi politik PITI kota Palembang pada pemilihan walikota tahun 2018. Dengan adanya ketiga faktor tersebut secara tidak langsung mendorong PITI untuk memberikan suaranya pada hari pemilihan tiba. Adapun faktor yang menjadi penghambat partisipasi PITI dalam pemilihan adalah organisasi cendrung menutup diri dari politik.

Dikatakan menutup diri dikarenakan organisasi PITI tidak berperan secara aktif sebagaimana organisasi lainya berani secara terang-terangan mendukung salah satu calon. PITI lebih memilih netral dan tidak mempublikasikan pilihannya kepada publik dan media. Walaupun pada kenyataanya ada calon kandidat walikota yang mendekati PITI tidak ingin dukungannya dilakukan secara terang-terangan dan tidak inigin organisasi bercampur menjadi satu dengan kegiatan politik. Sebagaimana telah dijelaskan sebelumnya bahwa dukungan dilakukan atas nama pribadi sehingga tidak terjadi mobilisasi suara organisasi dengan baik ke salah satu calon kandidat.

\section{KESIMPULAN}

Partisipasi Politik memiliki peran penting dalam perkembangan demokrasi dalam suatu negara. Partisipasi politik juga menjadi tolak ukur tingkat melek politik seseorang sebagai warga negara dalam perkembangan politik yang sedang terjadi. Banyak faktor yang mempengaruhi tinggi atau rendahnya partisipasi suatu masyarakat dalam suatu pemilihan kepala daerah. Partisipasi politik memiliki berbagai jenis dan cara yang berbeda-beda dalam implentasinya. Akan tetapi, dari beberapa teori besar yang ada mengenai partisipasi politik, dapat ditarik kesimpulan bahwa partisipasi politik yang bersifat pasif dan bersifat aktif.

Berdasarkan hasil penelitian yang telah dipaparkan pada bab sebelumnya, maka partisipasi politik PITI kota Palembang bersifat pasif. Dikarenakan PITI masih menutup diri dalam kegiatan yang berbau politik untuk masuk kedalam rana organisasinya. Dikatakan bersifat pasif juga merujuk pada tipe budaya politik yang masih dalam tingkat budaya politik kaula atau subjek. Dimana budaya politik kaula ini memiliki ciri bahwa masyarakat berpartispasi dalam kegiatan pemilihan, tapi tidak ikut lebih jauh dalam kegiatan politik.

Begitupun yang terjadi pada PITI kota Palembang, ia hanya berpartisipasi dalam kegiatan politik hanya sebatas dalam pemberian suara secara langsung pada hari pemilihan. Walaupun sebenarnya ada anggota yang ikut dalam kegiatan politik tapi tidak dapat dikatakan mewakili organisasi secara keseluruhan. Selain itu, identitas sebagai etnis Tionghoa yang dimiliki PITI tidak digunakan sebaik mungkin dalam menjalin hubungan politik dengan salah satu pasangan calon walikota pada pemilihan walikota Palembang tahun pengaruh modernisasi secara cepat di segala bidang. Diantaranya, yaitu pendidikan, media masa, dan kelompok kepentingan 


\section{DAFTAR PUSTAKA}

Abdi Sahrihal Harahap, "Dinamikia Pergerakan Persatuan Islam Tionghoa Indonesia (PITI) Medan Sumatera Utara,"Jurnal Analytica Islamica, Vol. 1, No. 2, 2012.

Budiardjo, Miriam. 2010. Dasar-dasar Ilmu Politik. Jakarta: PT Gramedia Pustaka Utama

Choilisin, dkk. Dasar-dasar Ilmu Politik. Yogyakarta: UNY Press, 2007.

Dalilan, Mikail, K. (2018). Ijtihad Politik Islam Palembang di Masa Orde Baru. Jurnal Politik Profetik, 6 (1), 31-53. Retrieved from http://journal.uinalauddin.ac.id/index.php/jpp/article/view/5807/5046

Damsar. 2010. Pengantar Sosiologi Politik. Jakarta: Prenada Media Group

Fitri Ramdhani Harahap,"Politik Identitas Berbasis Agama," dalam Proceeding Konferensi Nasional Sosiologi III, "Transformasi Demokrasi Indonesia Menuju Perubahan Yang Bermakna Yogyakarta", 20-22 Mei 2014.

Hamada Adzani Mahaswara, "Muslim Tioghoa sebagai Jembatan Budaya: Studi tentang Partisipasi dan Dinamika organisasi PITI Yogyakarta", JURNAL Shahih Vol. 2, Nomor 1, Januari - Juni 2017.

Handoyo, Eko. 2008. Sosiologi Politik. Semarang: UNNES Press

Hartati, R., Masyhur, M., \& Zalpa, Y. (2021). Perilaku Politik Budaya Jawa dalam Warga Buay Madang Timur Kabupaten OKU Timur. Ampera: A Research Journal on Politics and Islamic Civilization, 2(1), 15-24. https://doi.org/https://doi.org/10.19109/ampera.v2i1.7429

Herbert McClosky. "Political Participation" International Encyclopedia of the Social Sciences, edisi ke-2. New York: The Macmillan Company. 1972.

Husain Umar, 2003, Metode Riset Bisnis, Gramedia Pustaka Utama, Jakarta.

Ivan Devi Sagala dan Budi Ali Mukmin, "Politik Identitas Etnis dalam Pilkada Pemilihan Walikota dan Wakil Walikota Binjai Tahun 2015," Jurnal Antropologi Sosial dan Budaya 4 (1) (2018).

J.M. Sri Narhadi, "Kajian Bentuk, Fasad, dan Ruang dalam pada masjid Cheng Ho Palembang," Jurnal Arsitektur Zonasi Volume 2 - Nomor 3 - Oktober 2019.

Khotimah, "Agama dan Civil Society," Jurnal Ushulluddin Vol. XXI No. 1, Januari 2014 Melinda Adi Pratiwi, "Skripsi: Politik Identitas daalam Perspektif Politisi Tionghoa Surabaya" (UIN Sunan Ampel Surabaya tahun 2017).

Meolong. J. Lexy. 2009. Metode Penelitian Kualitatif. Bandung: PT.Remaja Rosdakarya.

Moh. Muhyudin, "Skripsi: Peran Persatuan Islam Tionghoa Indonesia (PITI) Terhadap Islamisasi di Indonesia,"(UIN Syarif Hidayatullah Jakarta tahun 2017.

Mohammad Maiwan, "Kelompok Kepentingan (interest group), Kekuasaan dan Kedudukannya dalam Sistem Politik", Jurnal Ilmiah Mimbar Demokrasi, Vol 15 No. 2, April 2016.

Pergiberwisata.com, "Masjid Cheng Ho Palembang-Wisata Relegi di Kota Palembang", diakses pada pukul 22:05, 16 April 2020.

Pokja Sanitasi Kota Palembang, Program Percepatan Pembangunan Sanitasi Permukiman (PPSP - 2010).

Rabith Jihan Amaruli dan Mahendra Pudji Utama, "Konversi Agama dan Formasi Identitas: Tionghoa Muslim Kudus Pasca-Indonesia Orde Baru,'Jurnal Humanika Vol. 22 No. 2, 2015.

Ramlan Surbakti. Memahami Ilmu Politik. Jakarta : PT Grasindo, 1999.

Rusadi Kantaprawira, Sistem Politik Indonesia. Bandung: Sinar Baru Algensindo 2004. 
Septian Adi Chandra, "Perkembangan Agama Islam di Kalangan Etnis Tionghoa

Semarang tahun 1972-1998," Journal of Indonesian History.

Sugiyono.2013. Metode Penelitian Kuantitatif Kualitatif Dan R\&D. Bandung:

Sumartono, "Budaya Politik dalam Masyarakat Pragmatis," Jurnal Lugas Vol. 2, No. 1, Juni 2018.

Surbakti, Ramlan. 1997. Partai, Pemilih, dan Demokrasi. Yogyakarta: Pustaka pelajar

Suryani dan Ana Sabhana Azmy, "Politik Identitas dan Nasionalisme Kebangsaan,"(Studi Atas Penguatan Politik Identitas Etnis Tionghoa di Indonesia Pasca Orde Baru), Tim Peneliti UIN Syarif Hidayatullah Jakarta tahun 2017.

Syhmpony Akelba Christian, "Identitas Budaya Orang Tionghoa Indonesia," Jurnal Cakrawala Mandarin Vol.1, No.1, April 2017.

Website KPU SUMSEL, http://jdih.kpu.go.id/sumsel/ “ Surat Keputisan Tentang Penetapan Nomor Urut Pasangan Calon Walikota Palembang Dalam Pemilihan Kepala Daerah Kota Palembang Tahun 2018, diakses pukul 23:39, 18 April 2020. Winarno Surakhmad, Pengantar Penelitian Ilmiah: Dasar, Metode, Teknik, cet. ke-7 (Jakarta: UI-press, 1994)

Zusneli Zubir dkk, Bunga Rampai: Sejarah Sumatera Selatan (Sumatera Selatan dalam Kajian Sosial dan Ekonomi), Padang: BPNST Padang Press, 2012.

Wawancara

1. Wawancara Langsung dengan Bapak Yanto selaku wakil PITI kota Palembang.

2. Wawancara Langsung dengan Ibu Meri selaku Seketaris kota Palembang.

3. Wawancara Langsung dengan Okta Priady sebagai anggota PITI kota Palembang. 